\title{
OVULATION BLOCK WITH STILBOESTROL IN THE COW
}

\author{
D. R. LAMOND \\ C.S.I.R.O., Division of Animal Physiology, Cunningham Laboratory, \\ St. Lucia, Queensland, Australia
}

(Received 22nd August 1968)

On theoretical grounds, one might expect to find a good deal of variation between cows in amounts of progesterone and oestrogen secreted by the ovary during the follicular phase of the oestrous cycle. Thus, there is variation in the rate of regression of corpora lutea (CL) in terms of size and progesterone content (Mares, Zimbelman \& Casida, 1962; Niswender, Kaltenbach, Shumway, Wiltbank \& Zimmerman, 1965), and limited data suggest that content is correlated with amounts of progesterone secreted into the ovarian vein (Gomes \& Erb, 1965). Although little is known about oestrogen content of ovarian vein blood, considerable variation has been observed in numbers of Graafian follicles during the follicular phase (Rajakoski, 1960; Choudary, Gier \& Marion, 1968; Lamond, unpublished). It seemed likely that variation in size of Graafian follicles might be associated with variation in ovarian steroid production. Consequently it was of interest to determine to what extent variation in oestrogen blood levels during the follicular phase of the cycle influences ovarian function.

Hereford heifers were kept in pens and fed a mixture of $60 \%$ hammer-milled lucerne hay and $40 \%$ crushed grain sorghum, sufficient to give liveweight gains of about $0.5 \mathrm{lb} /$ day. Ovarian cycles were synchronized using CAP (1-chloro$\Delta^{6}$-dehydro-17 $\alpha$-acetoxyprogesterone) or progesterone (Lamond, 1964, for details of synchronization methods). The heifers were given $12 \mathrm{mg}$ GAP/head/ day in the feed for 12 days, after which they were allocated at random to ten treatment groups (three to four heifers/group). Taking Day 1 as the day when feeding of CAP began, the treatments from Days 13 to 18 were as follows:

Group
1
2
3
4
5
6
7
8
9
10

Treatment from Day 13 to Day 18 inclusive
$40 \mathrm{mg}$ progesterone/day except Day 16
$40 \mathrm{mg}$ progesterone/day except Day 17
As for 1 , plus $100 \mu \mathrm{g}$ stilboestrol on Day 16
As for 2 , plus $100 \mu \mathrm{g}$ stilboestrol on Day 17
As for 1 , plus 1000 i.u. PMs on Day 16
$12 \mathrm{mg}$ CAP/day except Day 16
$12 \mathrm{mg}$ CAP/day except Day 17
As for 6 , plus $100 \mu \mathrm{g}$ stilboestrol on Day 16
As for 7, plus $100 \mu \mathrm{g}$ stilboestrol on Day 17
As for 6 , plus 1000 i.u. PMSG on Day 16

Progesterone was dissolved in arachis oil and given by intramuscular injection; stilboestrol dipropionate was dissolved in arachis oil and given by subcutaneous injection.

The ovaries of all heifers were examined for ovulation and for follicles greater 
than $0.7 \mathrm{~cm}$ approx. diameter, on Days 19 and 26, with an endoscope (Lamond \& Holmes, 1965). It was observed on Day 19 that three heifers had fully-grown corpora lutea and had presumably ovulated before Day 12. They were in Groups 3, 7 and 9. There were no ovulations in the remainder and each heifer had none to three follicles; there were no significant differences between treatments.

The results obtained on Day 26 are shown in Text-fig. 1. Except for those in Groups 3 and 8, the heifers ovulated between Days 21 and 23, as judged by visual examination. In Groups 3 and 8 (stilboestrol on Day 16) only one of seven heifers had ovulated. In most groups, up to three follicles were seen, but in Groups 3 and 4 there was excessive follicular development in some heifers.

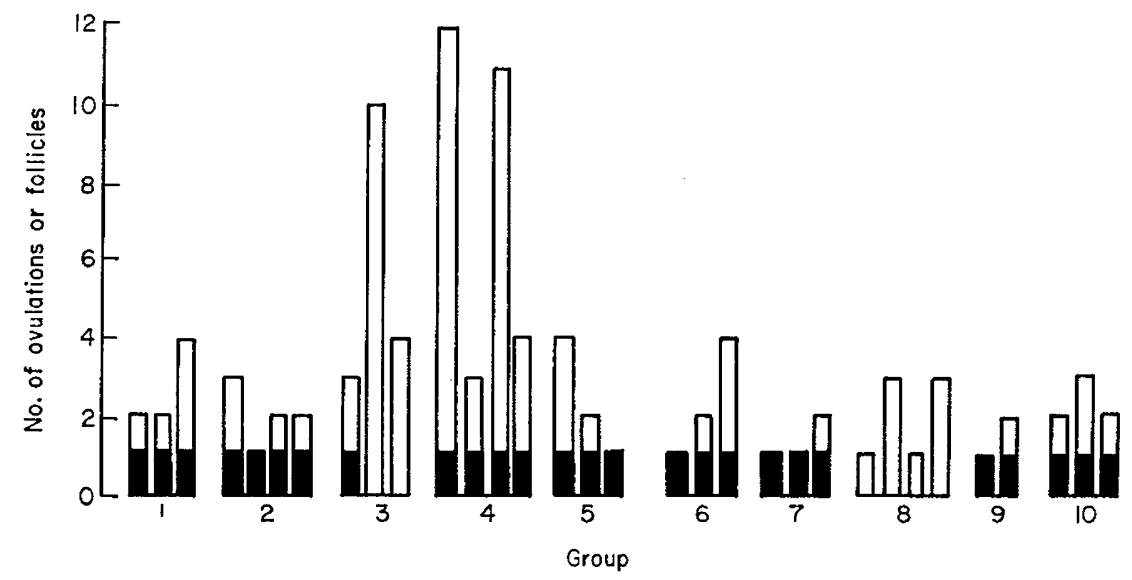

TEXT-FIG. 1. Results of ovarian examinations 8 days after the cessation of hormonal treatments. Each column (closed-ovulations; open-follicles) refers to one heifer.

The results indicate clearly that $100 \mu \mathrm{g}$ stilboestrol given 2 days, but not 1 day, before the end of a synchronization treatment, prevented ovulation from occurring 3 to 5 days later; this was independent of the progestagen used. Variation in follicle numbers was greatest in heifers treated with progesterone. The amount of oestrogen used was considerably less than that required to elicit oestrus in the ovariectomized cow (Melampy, Emmerson, Rakes, Hanka \& Eness, 1957; Lamond, unpublished). The results emphasize the need to investigate the relationship between blood levels of ovarian steroids during the period of luteal regression and follicular maturation and infertility in dairy and beef cows due to ovarian dysfunction.

I am indebted to B. M. Bindon and S. J. Marsh for assisting with the operations. The CAP was generously donated by Eli Lilly \& Co.

\section{REFERENCES}

Choudary, J. B., Gier, H. T. \& Marion, G. B. (1968) Cyclic changes in bovine vesicular follicles. F. Anim. Sci. 27, 468.

Gomes, W. R. \& ERB, R. E. (1965) Progesterone in bovine reproduction: a review. 7. Dairy Sci. 48, 314. 
LAMOND, D. R. (1964) Synchronization of ovarian cycles in sheep and cattle. Anim. Breed. Abstr. 32, 269.

LAMOND, D. R. \& Holmes, J. H. G. (1965) Suitable endoscope and laparotomy techniques for ovarian examination in the cow. Aust. vet. F. 41, 324.

Mares, S. E., Zimbelman, R. G. \& Casida, L. E. (1962) Variation in progesterone content of the bovine corpus luteum of the estrual cycle. F. Anim. Sci. 21, 266.

Melampy, R. M., Emmerson, M. A., Rakes, J. M., Hanka, L. J. \& Eness, P. G. (1957) The effect of progesterone on the estrous response of estrogen in conditioned ovariectomized cows. 7. Anim. Sci. 16,967.

Niswender, G. D., Kaltenbach, G. C., Shumway, R. P., Wiltbank, J. N. \& Zimmerman, D. R. (1965) Alteration of ovarian activity in cycling beef heifers with small daily injections of estradiol. 7. Anim. Sci. 24, 986.

RAjakoski, E. (1960) The ovarian follicular system in sexually mature heifers with special reference to seasonal, cyclical and left-right variations. Acta endocr., Copenh. 34, Suppl. 52. 